\title{
Expending Role of Microsatellite Instability in Diagnosis and Treatment of Colorectal Cancers
}

\author{
Liisa Chang $^{1} \cdot$ Minna Chang $^{2} \cdot$ Hanna M. Chang ${ }^{2} \cdot$ Fuju Chang $^{3,4}$ (D)
}

Published online: 11 July 2017

(C) The Author(s) 2017. This article is an open access publication

\begin{abstract}
Background Colorectal carcinomas with high-frequency microsatellite instability (MSI-H) account for $15 \%$ of all colorectal cancers, including $12 \%$ of sporadic cases and $3 \%$ of cancers associated with Lynch syndrome (also known as hereditary nonpolyposis colorectal cancer syndrome, HNPCC). Lynch syndrome is an autosomal dominant hereditary cancer syndrome, caused by germline mutations in mismatch repair genes, including MLH1, MSH2, MSH6 and PMS2.

Methods Published articles from peer-reviewed journals were obtained from PubMed, Google Scholar and Clinicaltrials.gov. Based on the recent research data, we provide an update on the MSI testing, along with the evolving role of MSI in diagnosis, prognosis and treatment of colorectal cancers.

Results Studies have led to significant advances in the molecular pathogenesis and clinicopathological characteristics of MSI-H colorectal cancers. Emerging evidence suggests that colorectal cancers with MSI-H show different outcome and treatment response from those with microsatellite stable (MSS) tumors. Therefore, MSI testing is essential not only in the genetic context, but it may also have important prognostic and predictive value of response to chemotherapy and immunotherapy.
\end{abstract}

Fuju Chang

fuju.chang@gstt.nhs.uk

1 Department of Medicine, Medway NHS Foundation Trust, Gillingham, Kent, UK

2 Faculty of Medicine, Imperial College London, South Kensington Campus, London, UK

3 Division of Cancer Studies, King's College London, London, UK

4 Department of Histopathology, Guy's \& St Thomas' Hospitals NHS Foundation Trust, Westminster Bridge Road, London SE1 7EH, UK
Conclusions Many experts and professional authorities have recommended a universal MSI testing in all individuals newly diagnosed with colorectal cancers.

Keywords Microsatellite instability $\cdot$ Mismatch repair $\cdot$ Lynch syndrome - Colorectal cancer · Cancer treatment .

Chemotherapy $\cdot$ Immunotherapy

\section{Introduction}

Colorectal cancer is a major health problem in Western countries, representing the second most commonly diagnosed malignancy in males and third in females and accounting for about 700,000 deaths per year [1,2]. The majority of colorectal cancers display chromosomal instability and follow the classical adenoma-carcinoma progressive pathway. However, a subset of $15 \%$ of colorectal cancers displays DNA mismatch repair (MMR) deficiency and shows highlevel microsatellite instability (MSI-H) [2, 3]. Colorectal cancers with MSI-H can occur as sporadic fashion or in the context of Lynch syndrome, also known as hereditary nonpolyposis colorectal cancer syndrome (HNPCC) [4, 5]. Thus, colorectal cancers can be classified under two molecular phenotypes, i.e., microsatellite stable (MSS) and microsatellite unstable or MSI-H phenotype [6].

MSI-H colorectal cancer has distinct clinicopathological features, including younger age of onset, proximal location, florid lymphocytic reaction, mucinous/signet ring differentiation and medullary growth pattern [6-8]. MSI is a critical DNA marker for the diagnosis of Lynch syndrome. Recent data also suggest that MSI status in colorectal cancers could provide valuable information for prognostic estimation and treatment stratification [9-11]. We provide here a brief review 
on recent development of MSI in diagnosis, prognosis and treatment of colorectal carcinoma.

\section{Microsatellite Instability Testing}

Lynch syndrome is caused by inherited defects in mismatch repair (MMR) genes MLH1, MSH2, MSH6 and PMS2 [4-6]. The presence of MSI-H and/or the absence of one or more of the MMR proteins by immunohistochemistry (IHC) in the tumor suggest MMR deficiency. MSI-H can be also caused by somatic hypermethylation of the MLH1 promoter, which is often associated with a BRAF c.1799T>A (p.V600E) mutation [12-14]. These somatic mutations are typically associated with sporadic colorectal carcinomas. MSI can be tested by either polymerase chain reaction (PCR)-based DNA technique or immunohistochemical staining on tumor tissue.

\section{Steps for the Microsatellite Instability DNA Testing}

MSI DNA testing is a PCR-based method that amplifies DNA at several microsatellite sites from a person's tumor tissue sample. Interpretation of the profiles requires a comparison with normal DNA from each patient. The National Cancer Institute Workshop agreed on five microsatellite markers necessary to determine MSI that include two mononucleotide markersBAT25/26 and three dinucleotide markers-D2S123, D5S346 and D17S250 [15, 16]. Some laboratories use commercially available testing kit, such as five-marker mononucleotide or quasimonomorphic panel [17, 18]. All of these markers are highly concordant with respect to the testing results [16]. Testing steps by PCR technique are listed in Table 1 .

Based on the MSI status, colorectal cancers can be classified into three groups: (1) if 30\% or more of the repeats are unstable, a tumor is classified as MSI-high (MSI-H); (2) if fewer than $30 \%$ of repeats are unstable, a tumor is classified as MSI-low (MSI-L); and (3) if no repeats are unstable, a tumor is classified as microsatellite stable (MSS) [16]. A MSI-L profile does not appear to be a good predictor of Lynch syndrome, so this result is grouped with the MSS type and does not lead to further testing.

Table 1 Steps for the microsatellite instability DNA testing

(1) Do a microsatellite instability test.

(2) If the microsatellite instability test result is positive, use sequential BRAF V600E and MLH1 promoter hypermethylation testing to differentiate sporadic and Lynch syndrome-associated colorectal cancers. First do a BRAF V600E test.

(3) If the BRAF V600E test is negative, do an MLH1 promoter hypermethylation test.

(4) If the MLH1 promoter hypermethylation test is negative, confirm Lynch syndrome by genetic testing of germline DNA.

\section{Steps for the Immunohistochemistry Testing}

Immunohistochemistry is widely used to identify the loss of one or more of the mismatch repair proteins (MLH1, MSH2, MSH6 and PMS2) $[6,8,16]$. These MMR proteins are usually expressed in normal tissue and show positive nuclear staining on IHC. The absence of specific staining suggests an underlying inactivation of one or more MMR genes. Tumors displaying loss of an MMR protein can be collectively referred to as MMR deficiency and are considered to be MSI$\mathrm{H}$, whereas those with intact MMR proteins are expected to be MSS or MSI-low [6, 8, 16].

The most common abnormal IHC staining pattern is simultaneous loss of MLH1 and PMS2, with normal staining of MSH2 and MSH6 (Fig. 1). This could indicate either Lynch syndrome or MMR deficiency in a sporadic tumor. Further testing for BRAF V600E mutation and MLH1 promoter hypermethylation can differentiate sporadic tumor from Lynch syndrome-associated cancer $[6,16]$. Testing steps by immunohistochemical staining are listed in Table 2. The other IHC profiles, such as combined MSH2/MSH6 loss or isolated loss of MSH6 or PMS2, are more likely to be associated with Lynch syndrome due to a germline mutation in one of these genes $[6,16]$. Germline mutation analysis can be done on blood leukocyte DNA or normal tissue of the patient.

\section{Concordance Rate Between MSI and IHC Testing}

Both MSI DNA testing and IHC are sensitive and specific. The reported sensitivity of MSI DNA testing is $89 \%$ for MLH1/MSH2 and 77\% for MSH6 [19]. The reported sensitivity of IHC for the MMR proteins is 77 to $83 \%$ [20, 21]. The concordance rate between IHC and MSI testing is over 92\% $[20,21]$. In practice, PCR and IHC testing often act as complementary tests; while both are sensitive and specific for mismatch repair deficiency, neither is perfect, and both will miss some mismatch repair-deficient tumors. To increase the detection rate, these two tests may be performed synergistically to detect cases that maybe missed by either test alone [22]. Easy performance and cost-effectiveness are two of the advantages of IHC. Moreover, IHC testing is helpful in identifying the specific defective protein and can guide germline testing to that specific gene.

\section{Diagnostic Role of MSI Testing}

\section{MSI Deficiency and Lynch Syndrome}

MSI deficiency is the hallmark of genetic aberration of Lynch syndrome [3-5]. This syndrome is an autosomal dominant disorder, caused by a germline mutation in one of the mismatch repair genes: MLH1, MSH2, MSH6 and 
Fig. 1 Immunohistochemistry for mismatch repair proteins in two colonic cancers. Patient 1 (panels a-e) shows a poorly differentiated adenocarcinoma (a) which is positive for MLH1 (b), MSH2 (c), MSH6 (d) and PMS2 (e), indicating MSS phenotype. Patient 2 (panels $\mathbf{f}-\mathbf{j}$ ) shows a moderately differentiated adenocarcinoma (f) with a MSI-H phenotype. Note the loss of nuclear staining for MLH1 (g) and PMS2 (j) but normal staining for MSH2 (h) and MSH6 (i). This tumor was subsequently tested for BRAF V600E and MLH1 promoter hypermethylation and did not reveal any abnormality. The findings in patient 2 are suggestive of Lynch syndrome; therefore, DNA germline testing is recommended

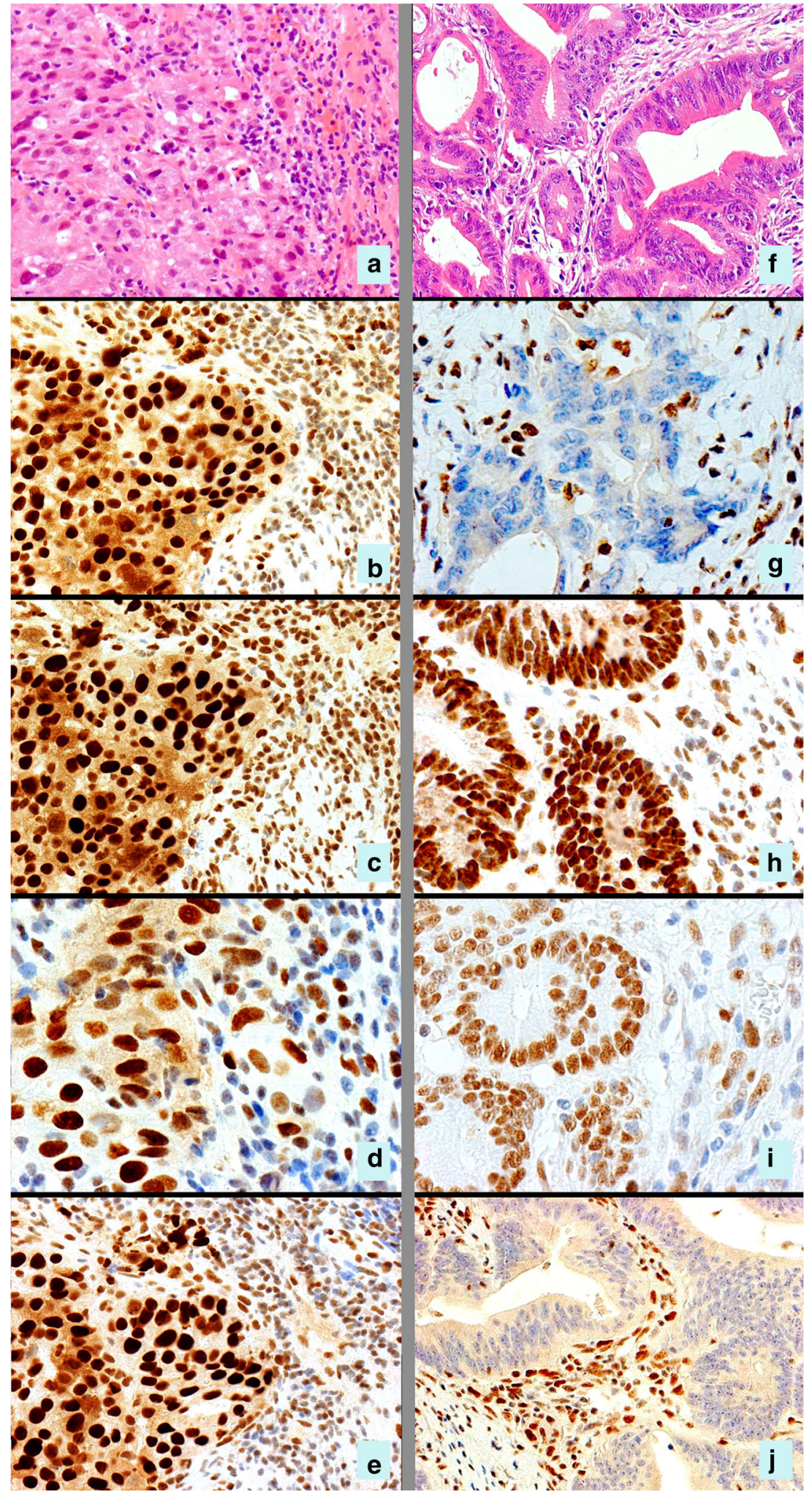

PMS2 [3-5, 20-23]. The majority of Lynch patients can be attributed to the mutation of MLH1 or MSH2, accounting for about $90 \%$ of the cases identified [23, 24]. The mutation of MSH6 only accounts for a small portion of
Lynch syndrome. Isolated loss of PMS2 is rare in patients with Lynch syndrome [23-25].

The flowchart in Fig. 2 shows MSI testing strategies for Lynch syndrome in people with colorectal cancer. 
Table 2 Steps for the immunohistochemistry testing

(1) Do an immunohistochemistry 4-panel test for MLH1, MSH2, MSH6 and PMS2.

(2) If the MLH1 immunohistochemistry result is abnormal, use sequential BRAF

(3) V600E and MLH1 promoter hypermethylation testing to differentiate sporadic and Lynch syndrome-associated colorectal cancers. First do a BRAF V600E test.

(4) If the BRAF V600E test is negative, do an MLH1 promoter hypermethylation test.

(5) If the MLH1 promoter hypermethylation test is negative, confirm Lynch syndrome by genetic testing of germline DNA.

In term of steps $2-4$, if the MSH2, MSH6 or PMS2 immunohistochemistry results are abnormal, confirm Lynch syndrome by subsequent genetic testing of germline DNA

Lynch syndrome accounts for about $3 \%$ (one in 30) of colorectal cancers and is estimated to lead to over 1100 colorectal cancers each year in the UK. The diagnosis of Lynch syndrome is essential since the patient has a high risk for developing many other cancers and needs appropriate surveillance. It is also important to identify family members carrying a defect MSI gene because they are at increased risk of developing cancers as well. The lifetime risk of colorectal cancer in individuals with Lynch syndrome is between 30 and $70 \%$, in contrast to $5.5 \%$ in the general population $[5,26]$. Patients with Lynch syndrome also have a high risk of developing extra-colorectal cancers, including endometrial carcinoma, ovary, small bowel, stomach, bladder, brain, kidney, biliary tract and gallbladder cancers, and skin sebaceous tumors
[27-29]. For endometrial cancer, the cumulative risk in Lynch syndrome patients by 70 years is between 32 and $42 \%[27,28]$.

Patients with Lynch syndrome have earlier age of colorectal cancer diagnosis at 44-61 years compared with 69 years in sporadic cases [26]. Approximately $70 \%$ of colon cancers in Lynch syndrome arise in the proximal colon [3]. Histologically, Lynch syndrome-related colorectal cancers tend to be mucinous and poorly differentiated with signet ring cells [6-8]. Another striking sign of MSI-H colorectal cancer is a high density of tumor-infiltrating lymphocytes [7]. Despite poor histological differentiation, the biological behavior of MSI-H colorectal carcinoma is less aggressive compared to that of MSS colorectal cancer [5-8].

\section{MSI Deficiency in Sporadic Colorectal Cancers}

MSI-H profile is observed in about $12 \%$ of sporadic colorectal cancers. The immunohistochemical finding in MSI-H sporadic tumors is usually simultaneous loss of MLH1 and PMS2. This is caused by MLH1 promoter hypermethylation, which is often associated with a BRAF c.1799T>A (p.V600E) mutation. This somatic mutation turns off the production of MLH1 mRNA and, therefore, the MLH1 protein is absent in cancer cells (Fig. 1) [30, 31]. The mutation of BRAF V600E gene is distinct in sporadic MSI-H tumors and not observed in tumors with germline mutations [32].

If loss of MLH1/PMS2 protein expression is observed, analysis of BRAF V600E mutation or analysis of methylation of the MLH1 promoter should be conducted to rule out a

\section{Flowchart showing molecular testing strategies for Lynch syndrome in people with colorectal cancer}

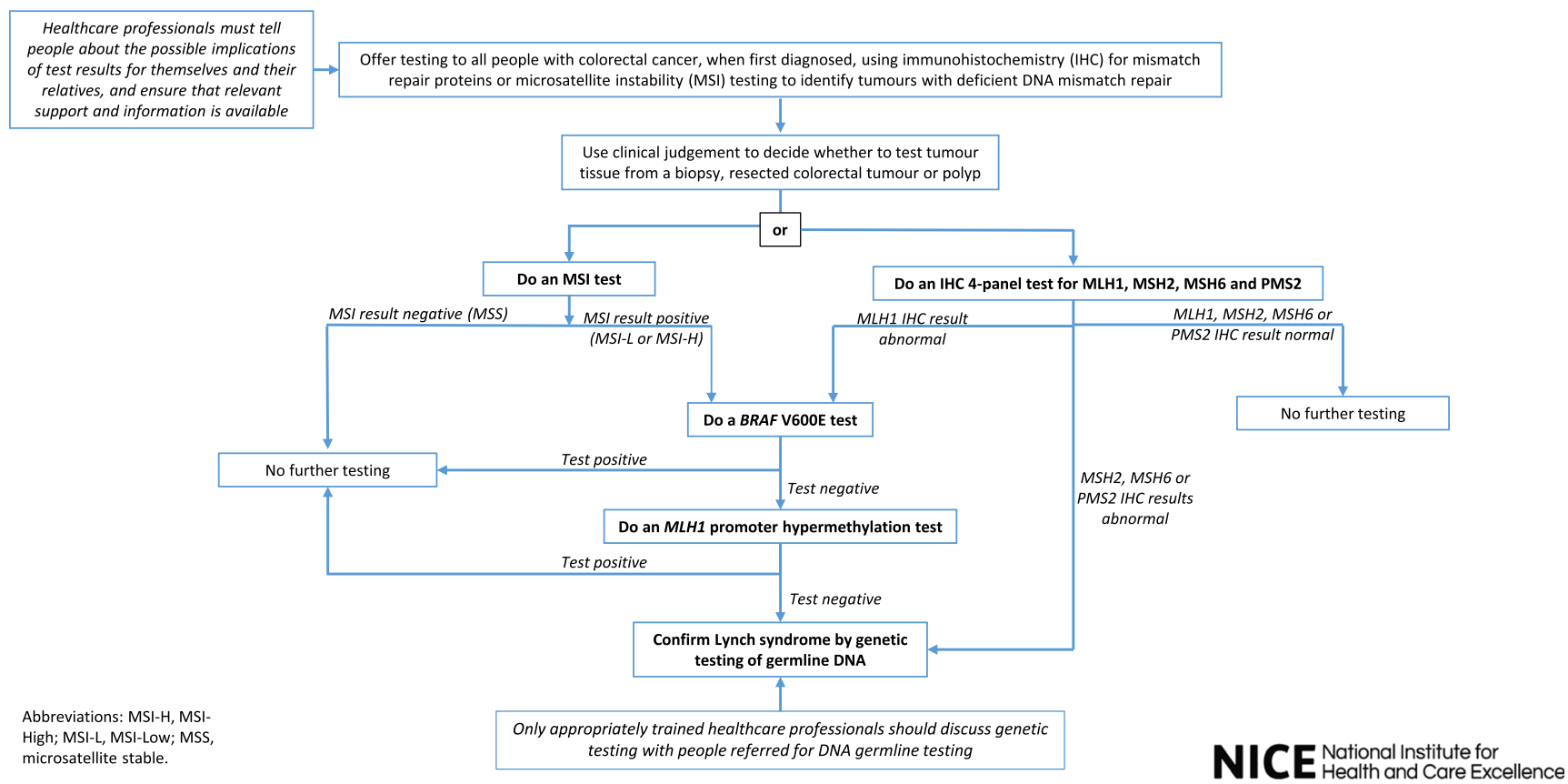

Fig. 2 NICE recommended universal screening strategy for Lynch syndrome Reproduced from reference [60] 
sporadic case. If tumor is MLH1/PMS2-deficient and somatic BRAF mutation is not detected or MLH1 promoter methylation is not identified, this MSI-H is less likely to be sporadic, and testing for germline mutations is indicated (Table 2).

\section{Prognostic Value of MSI Status for Colorectal Cancers}

MSI-H colorectal cancers, including sporadic and Lynch syndrome-related familial colorectal cancers, tend to have a less aggressive clinical behavior and a favorable prognosis compared to MSS tumors [33, 34]. This phenomenon has been repeatedly observed in retrospective studies, large trial studies and meta-analysis [35-38]. For instance, a recent meta-analysis from 32 studies with 1277 MSI-H cases included 7642 patients with stage I-IV colorectal cancers. The authors [38] found that cancers with MSI-H have a significantly better prognosis compared to those with MSS, i.e., intact mismatch repair. The estimated hazard ratio (HR) for overall survival associated with MSI-H was 0.65 (95\% confidence interval (CI), 0.59 to 0.71 ). This benefit was maintained restricting analyses to clinical trial patients $(\mathrm{HR}=0.69 ; 95 \% \mathrm{CI}, 0.56$ to 0.85$)$ and patients with locally advanced colorectal cancers $(\mathrm{HR}=0.67 ; 95 \% \mathrm{CI}, 0.58$ to 0.78 ). In a study of 2940 patients with stage I-III colorectal cancers who underwent complete resection, Kim et al. [39] noted that patients with MSI-H had a better clinical prognosis and these tumors were more often associated with local recurrence or peritoneal metastases, while the extra-abdominal recurrence was less frequent compared to MSI-L/MSS tumors. Mohan et al. [40] carried out a single-center study including 1250 colorectal patients and found that MSI-H was associated with a reduced risk of nodal and distant metastases, with an improved disease free survival (DFS) in stage I/II colorectal cancers. However, when MSI-H tumors progressed to stage III, these patients had worse outcomes and the tumors exhibited more aggressive pathological features including higher rates of lymphovascular invasion and perineural invasion than stage I/II MSI-H tumors. In a pooled analysis of 3063 patients from four phase III studies in first-line treatment of metastatic colorectal cancers, Venderbosch et al. [41] found patients with deficient MMR (dMMR) had significantly reduced progression-free survival and overall survival for advanced colorectal cancers and this poor prognosis of dMMR appears to be driven by BRAF mutation. These results suggest that the better prognosis of MSI-H tumors is more apparent for stage I/II early disease, but this predictive trend gradually disappears or even turns into a negative correlation as tumor progresses into advanced stages.

It has been suggested that the improved prognosis of MSI$\mathrm{H}$ cancers may be resulted from the pronounced anti-tumoral immune response of the host [42-44]. Tumors with MSI-H are hypermutated and express abundant peptides that serve as neoantigens to elicit a brisk immune response characterized by abundant tumor-infiltrating lymphocytes, including formation of lymphoid aggregates, medullary growth pattern and Crohn-like lymphocytic reaction [5, 7, 42, 43]. This represents an active immune response to the tumor, a known positive prognostic factor for colorectal carcinoma [42-44]. Due to unstable and hyper-mutational nature, colorectal cancers with MSI-H profile also tend to express high level of checkpoint proteins, including programmed death 1 (PD-1) and programmed death ligand 1 (PD-L1) [45], which makes MSI-H tumors more responsive to immunotherapy with PD-L1/PD-1 blockade (see the following discussion).

\section{Predictive Value of MSI Status for Colorectal Cancer Treatment}

\section{MSI Status and Chemotherapy Response}

Fluorouracil (5-FU) combined with leucovorin is considered as standard care for patients with stage II colorectal cancer. Data indicate that 5-FU-based adjuvant chemotherapy is ineffective in stage II cancer patients with MSI-H [46], consistent with the preclinical data showing that MMR deficiency is associated with 5-FU resistance in colorectal cancer cells $[47,48]$. Given the fact of favorable prognosis and lack of benefit from 5-FU-based adjuvant chemotherapy, many authors suggest that stage II colorectal cancer patients with a MSI-H phenotype should not be referred to adjuvant chemotherapy [49-53].

The chemotherapy regimen of folinic acid, 5-FU and oxaliplatin (FOLFOX), which is the standard adjuvant treatment regimen after surgical resection of stage III (lymph nodepositive) cancers or for metastatic disease, however, does appear to be effective in patients with MSI-H cancers, similar to their MSS countertype [54-57]. Therefore, stage III colorectal cancer patients can be offered for adjuvant FOLFOX treatment, irrespective of MMR status. However, so far only limited data are available from prospective clinical trials and further studies are required. Nevertheless, knowing the MSI status of the patient may help oncologists to draw up a most appropriate, personalized treatment plan.

\section{MSI Status and Immunotherapy Response}

Recent studies have shown that metastatic colorectal cancers with MSI-H respond favorably to immune checkpoint inhibitors $[11,58,59]$. These tumors tend to have high expression of checkpoint proteins, including PD-1 and PD-L1, which interfere with the body's antitumor T cell response. By disabling these proteins, checkpoint inhibitors enable T cells to attack and kill tumor cells, allowing the immune system to do its job more effectively [11, 58-60]. 
Le et al. [11] conducted a phase II trial in patients with metastatic colorectal cancers with or without MMR deficiency to evaluate the clinical activity of an antibody to PD-1 receptor, called pembrolizumab (Keytruda). Patients with MSI-H colorectal cancers and other carcinomas with MSI-H profile, including endometrial, gastric, small bowel carcinomas and ampullary or cholangiocarcinoma, had high rates of immune-related objective response (40 and $71 \%$, respectively) and high rates of immune-related progression-free survival at 20 weeks (78 and 67\%). No responses were seen in MSS colorectal cancer patients, and the 20 -week progression-free survival was only $11 \%$.

More recently, the promising antitumor activity of nivolumab (Opdivo), another anti-PD-1 monoclonal antibody, in patients with MSI-H metastatic colorectal cancers was also sustained in an update of the phase II CheckMate-142 trial presented at the 2017 Gastrointestinal Cancers Symposium [61]. At a median follow-up of 7.4 months (range, 0.325.3), the overall response rate with single-agent nivolumab in a cohort of $74 \mathrm{MSI}-\mathrm{H}$ patients was $31.1 \%$. The median progression-free survival (PFS) was 9.6 months $(95 \% \mathrm{CI}$, 4.3-NE), and the 12-month PFS rate was $48.4 \%$ (95\% CI, 33.6-61.7). The median overall survival (OS) had not been reached (95\% CI, 17.1-NE), and the 12-month OS rate was 73.8\% (95\% CI, 59.8-83.5). Treatment was well-tolerated, with no new safety signals.

These results suggest that MSI status may have significant implication in therapeutic options. Immune checkpoint blockade inhibition is less toxic than chemotherapeutic regimens and can provide significant benefits to the advanced cancer patients whose conditions are usually weak. If microsatellite stability is validated as a biomarker of immune checkpoint inhibitor efficacy, it will prove exceptionally useful in selecting patients most likely to benefit from such therapies.

In theory, immune checkpoint inhibition may benefit patients with earlier-stage disease as well, and this is an important research question to be addressed in the near future. Positive results in these groups could potentially spare these patients' chemotherapy and expand the number of patients who could benefit from less toxic immunotherapy.

\section{Ere of Universal MSI Testing}

Lynch syndrome is currently under-recognized, underdiagnosed and under-managed. For example, an estimated 175,000 people have Lynch syndrome in the UK but a staggering $95 \%$ of those do not know they have it. This is due to lacking of efficient, systematic testing system [62]. It is vital that people who have Lynch syndrome are identified, so they can take steps to reduce their risk of recurrence or for family members, of preventing cancer from developing.
MSI testing with either immunohistochemistry or PCRbased method is found to be cost-effective, sensitive, specific and is getting widely accepted. Therefore, several organizations including the US Multi-Society Task Force on Colorectal Cancer [26], the US National Comprehensive Cancer Network (NCCN) [63] and the UK National Institute for Health and Care Excellence (NICE) [64] have recommended testing all patients with colorectal cancer for Lynch syndrome; the tumor should be tested for mismatch repair by either DNA analysis or immunohistochemistry for MLH1, MSH2, MSH6 and PMS2 proteins.

Expanding MSI testing to all people with colorectal cancer will certainly increase the detection of Lynch syndrome. This can lead to increased surveillance and improved patient outcomes through earlier diagnosis and treatment. Meanwhile, given the evolving role of MSI in prognostic estimation and therapeutic efficiency prediction, the universal testing will have important implications in colorectal cancer diagnosis and personalized therapeutic approach.

\section{Conclusion}

Screening for MSI-H colorectal cancers is clinically significant in detecting Lynch syndrome, predicting prognosis and determining the application of oncological treatment for colorectal cancers. Recent studies on the potential role of MSI in targeted immunotherapy for metastatic colorectal carcinomas have shown that testing MSI status in these patients may be critical in precision medicine [11, 58-60]. There is a clear trend toward universal testing of newly diagnosed colorectal cancers for evidence of microsatellite instability. Notably, some of extra-colonic cancers, such as endometrial carcinoma, gastric carcinoma and ovarian carcinoma, also exhibit MSI-H profile, and it is possible that MSI status may eventually become an important prognostic and predictive marker in tumors beyond the colon [65-67]. At the present moment, multiple clinical trials are ongoing, and in the near future, our knowledge about MSI in targeted immunotherapy will increase as a consequence of the completion of these ongoing studies.

\section{Compliance with Ethical Standards}

\section{Conflict of Interest None.}

Open Access This article is distributed under the terms of the Creative Commons Attribution 4.0 International License (http:// creativecommons.org/licenses/by/4.0/), which permits unrestricted use, distribution, and reproduction in any medium, provided you give appropriate credit to the original author(s) and the source, provide a link to the Creative Commons license, and indicate if changes were made. 


\section{References}

1. Jemal A, Bray F, Center MM, Ferlay J, Ward E, Forman D. Global cancer statistics. CA Cancer J Clin. 2011;61:69-90.

2. Siegel R, Naishadham D, Jemal A. Cancer statistics, 2013. CA Cancer J Clin. 2013;63:11-30.

3. Lynch HT, de la Chapelle A. Hereditary colorectal cancer. N Engl J Med. 2003;348:919-32.

4. Boland CR, Goel A. Microsatellite instability in colorectal cancer. Gastroenterology. 2010;138:2073-87.

5. Lynch HT, Synder CL, Shaw TG. Milestones of Lynch syndrome: 1895-2015. Nat Rev Cancer. 2015;15:181-94.

6. Wade S. Samowitz, Evaluation of colorectal cancers for Lynch syndrome: practical molecular diagnostics for surgical pathologists. Mod Pathol. 2015;28:S109-S13.

7. Smyrk TC, Watson P, Kaul K, Lynch HT. Tumor-infiltrating lymphocytes are a marker for microsatellite instability in colorectal carcinoma. Cancer. 2001;91:2417-22.

8. Shia J, Ellis NA, Paty PB, Nash GM, Qin J, Offit K, Zhang XM, Markowitz AJ, Nafa K, Guillem JG, Wong WD, Gerald WL, Klimstra DS. Value of histopathology in predicting microsatellite instability in hereditary nonpolyposis colorectal cancer and sporadic colorectal cancer. Am J Surg Pathol. 2003;27:1407-17.

9. Carethers JM, Smith EJ, Behling CA, Nguyen L, Tajima A, Doctolero RT, Cabrera BL, Goel A, Arnold CA, Miyai K, Boland CR. Use of 5-fluorouracil and survival in patients with microsatellite-unstable colorectal cancer. Gastroenterology. 2004;126:394-401.

10. Ribic CM, Sargent DJ, Moore MJ, Thibodeau SN, French AJ, Goldberg RM, Hamilton SR, Laurent-Puig P, Gryfe R, Shepherd LE, Tu D, Redston M, Gallinger S. Tumor microsatellite instability status as a predictor of benefit from fluorouracil-based adjuvant chemotherapy for colon cancer. N Engl J Med. 2003;349:247-57.

11. Le DT, Uram JN, Wang H, Bartlett BR, Kemberling H, Eyring AD, Skora AD, Luber BS, Azad NS, Laheru D, Biedrzycki B, Donehower RC, Zaheer A, Fisher GA, Crocenzi TS, Lee JJ, Duffy SM, Goldberg RM, de la Chapelle A, Koshiji M, Bhaijee F, Huebner T, Hruban RH, Wood LD, Cuka N, Pardoll DM, Papadopoulos N, Kinzler KW, Zhou S, Cornish TC, Taube JM, Anders RA, Eshleman JR, Vogelstein B, Diaz LA Jr. PD-1 blockade in tumors with mismatch-repair deficiency. N Engl J Med. 2015;372:2509-20.

12. Deng G, Bell I, Crawley S, Gum J, Terdiman JP, Allen BA, Truta B, Sleisenger $\mathrm{MH}, \mathrm{Kim}$ YS. BRAF mutation is frequently present in sporadic colorectal cancer with methylated hMLH1, but not in hereditary nonpolyposis colorectal cancer. Clin Cancer Res. 2004;10: 191-5.

13. Domingo E, Laiho P, Ollikainen M, Pinto M, Wang L, French AJ, Westra J, Frebourg T, Espín E, Armengol M, Hamelin R, Yamamoto H, Hofstra RM, Seruca R, Lindblom A, Peltomäki P, Thibodeau SN, Aaltonen LA, Schwartz S Jr. BRAF screening as a low-cost effective strategy for simplifying HNPCC genetic testing. J Med Genet. 2004;41:664-8.

14. Fearon ER. Molecular genetics of colorectal cancer. Annu Rev Pathol. 2011;6:479-507.

15. Boland CR, Thibodeau SN, Hamilton SR, Sidransky D, Eshleman JR, Burt RW, Meltzer SJ, Rodriguez-Bigas MA, Fodde R, Ranzani GN, Srivastava S. A National Cancer Institute workshop on microsatellite instability for cancer detection and familial predisposition: development of international criteria for the determination of microsatellite instability in colorectal cancer. Cancer Res. 1998;58: 5248-57.

16. Hegde M, Ferber M, Mao R, Samowitz W, Ganguly A, Working Group of the American College of Medical Genetics and Genomics (ACMG) Laboratory Quality Assurance Committee. ACMG technical standards and guidelines for genetic testing for inherited colorectal cancer (Lynch syndrome, familial adenomatous polyposis, and MYH-associated polyposis). Genet Med. 2014;16: 101-16.

17. Buhard O, Suraweera N, Lectard A, Duval A, Hamelin R. Quasimonomorphic mononucleotide repeats for high-level microsatellite instability analysis. Dis Markers. 2004;20:251-7.

18. Suraweera N, Duval A, Reperant M, Vaury C, Furlan D, Leroy K, Seruca R, Iacopetta B, Hamelin R. Evaluation of tumor microsatellite instability using five quasimonomorphic mononucleotide repeats and pentaplex PCR. Gastroenterology. 2002;123:1804-11.

19. Palomaki GE, McClain MR, Melillo S, Hampel HL, Thibodeau SN. EGAPP supplementary evidence review: DNA testing strategies aimed at reducing morbidity and mortality from Lynch syndrome. Genet Med. 2009;1:42-65.

20. Shia J, Ellis NA, Klimstra DS. The utility of immunohistochemical detection of DNA mismatch repair gene proteins. Virchows Arch. 2004;445:431-41.

21. Shia J. Immunohistochemistry versus microsatellite instability testing for screening colorectal cancer patients at risk for hereditary nonpolyposis colorectal cancer syndrome. Part I. The utility of immunohistochemistry. J Mol Diagn. 2008;10:293-300.

22. Shia J, Stadler Z, Weiser MR, Rentz M, Gonen M, Tang LH, Vakiani E, Katabi N, Xiong X, Markowitz AJ, Shike M, Guillem J, Klimstra DS. Immunohistochemical staining for DNA mismatch repair proteins in intestinal tract carcinoma: how reliable are biopsy samples? Am J Surg Pathol. 2011;35:447-54.

23. Casey G, Lindor NM, Papadopoulos N, Thibodeau SN, Moskow J, Steelman S, Buzin CH, Sommer SS, Collins CE, Butz M, Aronson M, Gallinger S, Barker MA, Young JP, Jass JR, Hopper JL, Diep A, Bapat B, Salem M, Seminara D, Haile R, Colon Cancer Family Registry. Conversion analysis for mutation detection in MLH1 and MSH2 in patients with colorectal cancer. JAMA. 2005;293: 799-809.

24. Bonadona V, Bonaïti B, Olschwang S, Grandjouan S, Huiart L, Longy M, Guimbaud R, Buecher B, Bignon YJ, Caron O, Colas $\mathrm{C}$, Noguès $\mathrm{C}$, Lejeune-Dumoulin $\mathrm{S}$, Olivier-Faivre L, PolycarpeOsaer F, Nguyen TD, Desseigne F, Saurin JC, Berthet P, Leroux D, Duffour J, Manouvrier S, Frébourg T, Sobol H, Lasset C, BonaïtiPellié C, French Cancer Genetics Network. Cancer risks associated with germline mutations in MLH1, MSH2, and MSH6 genes in Lynch syndrome. JAMA. 2011;305:2304-10.

25. Gill S, Lindor NM, Burgart LJ, Smalley R, Leontovich O, French AJ, Goldberg RM, Sargent DJ, Jass JR, Hopper JL, Jenkins MA, Young J, Barker MA, Walsh MD, Ruszkiewicz AR, Thibodeau SN. Isolated loss of PMS2 expression in colorectal cancers: frequency, patient age, and familial aggregation. Clin Cancer Res. 2005;11: 6466-71.

26. Giardiello FM, Allen JI, Axilbund JE, Boland CR, Burke CA, Burt RW, Church JM, Dominitz JA, Johnson DA, Kaltenbach T, Levin TR, Lieberman DA, Robertson DJ, Syngal S, Rex DK. Guidelines on genetic evaluation and management of Lynch syndrome: a consensus statement by the US Multi-Society Task Force on Colorectal Cancer. Am J Gastroenterol. 2014;109:1159-79.

27. Aarnio M, Sankila R, Pukkala E, Salovaara R, Aaltonen LA, de la Chapelle A, Peltomäki P, Mecklin JP, Järvinen HJ. Cancer risk in mutation carriers of DNA-mismatch-repair genes. Int J Cancer. 1999;81:214-8

28. Bansidhar BJ. Extracolonic manifestations of Lynch syndrome. Clin Colon Rectal Surg. 2012;25:103-10.

29. Williams AS, Huang WY. The analysis of microsatellite instability in extracolonic gastrointestinal malignancy. Pathology. 2013;45: $540-52$

30. Kim JH, Shin SH, Kwon HJ, Cho NY, Kang GH. Prognostic implications of $\mathrm{CpG}$ island hypermethylator phenotype in colorectal cancers. Virchows Arch. 2009;455:485-94. 
31. Thibodeau SN, French AJ, Cunningham JM, Tester D, Burgart LJ, Roche PC, McDonnell SK, Schaid DJ, Vockley CW, Michels VV, Farr GH Jr, O'Connell MJ. Microsatellite instability in colorectal cancer: different mutator phenotypes and the principal involvement of hMLH1. Cancer Res. 1998;58:1713-8.

32. Hall G, Clarkson A, Shi A, Langford E, Leung H, Eckstein RP, Gill AJ. Immunohistochemistry for PMS2 and MSH6 alone can replace a four antibody panel for mismatch repair deficiency screening in colorectal adenocarcinoma. Pathology. 2010;42:409-13.

33. Roth AD, Delorenzi M, Tejpar S, Yan P, Klingbiel D, Fiocca R, d'Ario G, Cisar L, Labianca R, Cunningham D, Nordlinger B, Bosman F, Van Cutsem E. Integrated analysis of molecular and clinical prognostic factors in stage II/III colon cancer. J Natl Cancer Inst. 2012;104:1635-46.

34. Merok MA, Ahlquist T, Røyrvik EC, Tufteland KF, Hektoen M, Sjo $\mathrm{OH}$, Mala T, Svindland A, Lothe RA, Nesbakken A. Microsatellite instability has a positive prognostic impact on stage II colorectal cancer after complete resection: results from a large, consecutive Norwegian series. Ann Oncol. 2013;24:1274-82.

35. Sinicrope FA, Foster NR, Thibodeau SN, Marsoni S, Monges G, Labianca R, Kim GP, Yothers G, Allegra C, Moore MJ, Gallinger S, Sargent DJ. DNA mismatch repair status and colon cancer recurrence and survival in clinical trials of 5-fluorouracil-based adjuvant therapy. J Natl Cancer Inst. 2011;103:863-75.

36. Sargent DJ, Marsoni S, Monges G, Thibodeau SN, Labianca R, Hamilton SR, French AJ, Kabat B, Foster NR, Torri V, Ribic C, Grothey A, Moore M, Zaniboni A, Seitz JF, Sinicrope F, Gallinger S. Defective mismatch repair as a predictive marker for lack of efficacy of fluorouracil-based adjuvant therapy in colon cancer. $\mathrm{J}$ Clin Oncol. 2010;28:3219-26.

37. Sinicrope FA, Mahoney MR, Smyrk TC, Thibodeau SN, Warren RS, Bertagnolli MM, Nelson GD, Goldberg RM, Sargent DJ, Alberts SR. Prognostic impact of deficient DNA mismatch repair in patients with stage III colon cancer from a randomized trial of FOLFOX-based adjuvant chemotherapy. J Clin Oncol. 2013;31: 3664-72.

38. Popat S, Hubner R, Houlston RS. Systematic review of microsatellite instability and colorectal cancer prognosis. J Clin Oncol. 2005;23:609-18.

39. Kim CG, Ahn JB, Jung M, Beom SH, Kim C, Kim JH, Heo SJ, Park HS, Kim JH, Kim NK, Min BS, Kim H, Koom WS, Shin SJ. Effects of microsatellite instability on recurrence patterns and outcomes in colorectal cancers. Br J Cancer. 2016;115:25-33.

40. Mohan HM, Ryan E, Balasubramanian I, Kennelly R, Geraghty R, Sclafani F, Fennelly D, McDermott R, Ryan EJ, O'Donoghue D, Hyland JM, Martin ST, O'Connell PR, Gibbons D, Winter D, Sheahan K. Microsatellite instability is associated with reduced disease specific survival in stage III colon cancer. Eur J Surg Oncol. 2016;42:1680-6.

41. Venderbosch S, Nagtegaal ID, Maughan TS, Smith CG, Cheadle JP, Fisher D, Kaplan R, Quirke P, Seymour MT, Richman SD, Meijer GA, Ylstra B, Heideman DA, de Haan AF, Punt CJ, Koopman M. Mismatch repair status and BRAF mutation status in metastatic colorectal cancer patients: a pooled analysis of the CAIRO, CAIRO2, COIN, and FOCUS studies. Clin Cancer Res. 2014;20: 5322-30.

42. Rosenbaum MW, Bledsoe JR, Morales-Oyarvide V, Huynh TG, Mino-Kenudson M. PD-L1 expression in colorectal cancer is associated with microsatellite instability, BRAF mutation, medullary morphology and cytotoxic tumor-infiltrating lymphocytes. Mod Pathol. 2016;29:1104-12.

43. Lanza G, Gafà R, Santini A, Maestri I, Guerzoni L, Cavazzini L. Immunohistochemical test for MLH1 and MSH2 expression predicts clinical outcome in stage II and III colorectal cancer patients. J Clin Oncol. 2006;24:2359-67.
44. Samowitz WS, Curtin K, Ma KN, Schaffer D, Coleman LW, Leppert M, Slattery ML. Microsatellite instability in sporadic colon cancer is associated with an improved prognosis at the population level. Cancer Epidemiol Biomark Prev. 2001;10:917-23.

45. Llosa NJ, Cruise M, Tam A, Wicks EC, Hechenbleikner EM, Taube JM, Blosser RL, Fan H, Wang H, Luber BS, Zhang M, Papadopoulos N, Kinzler KW, Vogelstein B, Sears CL, Anders RA, Pardoll DM, Housseau F. The vigorous immune microenvironment of microsatellite instable colon cancer is balanced by multiple counter-inhibitory checkpoints. Cancer Discov. 2015;5:43-51.

46. Vilar E, Gruber SB. Microsatellite instability in colorectal cancerthe stable evidence. Nat Rev Clin Oncol. 2010;7:153-62.

47. Meyers M, Wagner MW, Hwang HS, Kinsella TJ, Boothman DA. Role of the hMLH1 DNA mismatch repair protein in fluoropyrimidine-mediated cell death and cell cycle responses. Cancer Res. 2001;61:5193-201.

48. Arnold CN, Goel A, Boland CR. Role of hMLH1 promoter hypermethylation in drug resistance to 5-fluorouracil in colorectal cancer cell lines. Int J Cancer. 2003;106:66-73.

49. Copija A, Waniczek D, Witkoś A, Walkiewicz K, NowakowskaZajdel E. Clinical significance and prognostic relevance of microsatellite instability in sporadic colorectal cancer patients. Int J Mol Sci. 2017;18(1). pii: E107. doi: 10.3390/ijms18010107.

50. Strâmbu V, Garofil D, Pop F, Radu P, Brătucu M, Iorga C, Iorga R, Pasnicu C, Ion A, Popa F. Microsatellite instability in the management of stage II colorectal patients. Chirurgia (Bucur). 2013;108: 816-21.

51. Gelsomino F, Barbolini M, Spallanzani A, Pugliese G, Cascinu S. The evolving role of microsatellite instability in colorectal cancer: a review. Cancer Treat Rev. 2016;51:19-26.

52. Sinicrope FA. DNA mismatch repair and adjuvant chemotherapy in sporadic colon cancer. Nat Rev Clin Oncol. 2010;7:174-7.

53. Jover R, Zapater P, Castells A, Llor X, Andreu M, Cubiella J, Balaguer F, Sempere L, Xicola RM, Bujanda L, Reñé JM, Clofent J, Bessa X, Morillas JD, Nicolás-Pérez D, Pons E, Payá A, Alenda C, Gastrointestinal Oncology Group of the Spanish Gastroenterological Association. The efficacy of adjuvant chemotherapy with 5-fluorouracil in colorectal cancer depends on the mismatch repair status. Eur J Cancer. 2009;45:365-73.

54. Des Guetz G, Lecaille C, Mariani P, Bennamoun M, Uzzan B, Nicolas P, Boisseau A, Sastre X. Prognostic impact of microsatellite instability in colorectal cancer patients treated with adjuvant FOLFOX. Anticancer Res. 2010;30:4297-301.

55. Kim ST, Lee J, Park SH, Park JO, Lim HY, Kang WK, Kim JY, Kim YH, Chang DK, Rhee PL, Kim DS, Yun H, Cho YB, Kim HC, Yun SH, Lee WY, Chun HK, Park YS. Clinical impact of microsatellite instability in colon cancer following adjuvant FOLFOX therapy. Cancer Chemother Pharmacol. 2010;66:659-67.

56. Zaanan A, Cuilliere-Dartigues P, Guilloux A, Parc Y, Louvet C, de Gramont A, Tiret E, Dumont S, Gayet B, Validire P, Fléjou JF, Duval A, Praz F. Impact of p53 expression and microsatellite instability on stage III colon cancer disease-free survival in patients treated by 5 -fluorouracil and leucovorin with or without oxaliplatin. Ann Oncol. 2010;21:772-80.

57. Kawakami H, Zaanan A, Sinicrope FA. Microsatellite instability testing and its role in the management of colorectal cancer. Curr Treat Options in Oncol. 2015;16:30. doi:10.1007/s11864-0150348-2.

58. Kim JH, Park HE, Cho NY, Lee HS, Kang GH. Characterisation of PD-L1-positive subsets of microsatellite-unstable colorectal cancers. Br J Cancer. 2016;115:490-6.

59. Dudley JC, Lin MT, Le DT, Eshleman JR. Microsatellite instability as a biomarker for PD-1 blockade. Clin Cancer Res. 2016;22:81320.

60. Bever KM, Le DT. An expanding role for immunotherapy in colorectal cancer. J Natl Compr Cancer Netw. 2017;15:401-10. 
61. Overman MJ, Lonardi S, Leone F, McDermott RS, Morse MA, Wong KYM, Neyns B, Leach JL, Alfonso PG, Lee JJ, Hill A, Lenz HJ, Desai J, Moss RA, Cao ZA, Ledeine JM, Tang H, Kopetz S, Andre T. Nivolumab in patients with DNA mismatch repair deficient/microsatellite instability high metastatic colorectal cancer: update from CheckMate 142. J Clin Oncol 2017; 35: 4_suppl, 519-519. DOI: 10.1200/JCO.2017.35.4_suppl.519.

62. Anne Gulland. All patients with colorectal cancer should be tested for genetic condition, NICE advises. BMJ. 2017;356:j998 doi: 10. 1136/bmj.j998.

63. Hampel H. NCCN increases the emphasis on genetic/familial highrisk assessment in colorectal cancer. J Natl Compr Cancer Netw. 2014;12(Suppl):829-31.

64. National Institute for Health and Care Excellence. Molecular testing strategies for Lynch syndrome in people with colorectal cancer.
2017. www.nice.org.uk/guidance/dg27/chapter/1Recommendations.

65. Naboush A, Roman CA, Shapira I. Immune checkpoint inhibitors in malignancies with mismatch repair deficiency: a review of the state of the current knowledge. J Investig Med. 2017;65:754-8.

66. Howitt BE, Strickland KC, Sholl LM, Rodig S, Ritterhouse LL, Chowdhury D, D'Andrea AD, Matulonis UA, Konstantinopoulos PA. Clear cell ovarian cancers with microsatellite instability: a unique subset of ovarian cancers with increased tumor-infiltrating lymphocytes and PD-1/PD-L1 expression. Oncoimmunology. 2017;6(2):e1277308. doi:10.1080/2162402X.2016.1277308.

67. Cho J, Lee J, Bang H, Kim ST, Park SH, An JY, Choi MG, Lee JH, Sohn TS, Bae JM, Kang WK, Kim S, Kim KM. Programmed cell death-ligand 1 expression predicts survival in patients with gastric carcinoma with microsatellite instability. Oncotarget. 2017;8(8): 13320-8. doi:10.18632/oncotarget.14519. 